\title{
Industrial characterization of nano-scale roughness on polished surfaces
}

Feidenhans'I, Nikolaj Agentoft; Hansen, Poul-Erik; Pilny, Lukas; Madsen, Morten H.; Bissacco, Giuliano; Petersen, Jan C.; Taboryski, Rafael J.

\section{Published in:}

Proceedings of SPIE - The International Society for Optical Engineering

Link to article, DOI:

$10.1117 / 12.2197242$

Publication date:

2015

Document Version

Peer reviewed version

Link back to DTU Orbit

Citation (APA):

Feidenhans'l, N. A., Hansen, P-E., Pilny, L., Madsen, M. H., Bissacco, G., Petersen, J. C., \& Taboryski, R. J. (2015). Industrial characterization of nano-scale roughness on polished surfaces. Proceedings of SPIE - The International Society for Optical Engineering, 9633. https://doi.org/10.1117/12.2197242

\section{General rights}

Copyright and moral rights for the publications made accessible in the public portal are retained by the authors and/or other copyright owners and it is a condition of accessing publications that users recognise and abide by the legal requirements associated with these rights.

- Users may download and print one copy of any publication from the public portal for the purpose of private study or research.

- You may not further distribute the material or use it for any profit-making activity or commercial gain

- You may freely distribute the URL identifying the publication in the public portal 


\section{Title}

Industrial characterization of nano-scale roughness on polished surfaces

\section{Abstract (250 words)}

Manufacturing of nanostructured polymer devices set strict demands on the smoothness of the mold master. High quality polishing of the manufacturing master is obtainable with present industrial polishing methods, but only few instruments allow in-process characterization of the samples.

In this work, we compare three optical methods for characterizing nanoscale roughness: a laboratory scatterometer measuring the angular distribution of light scattered from a surface, a confocal 3D optical profiler, and an industrial scatterometer called an OptoSurf, which is designed for in-situ characterization.

The roughness parameters evaluated are: the root-mean-square height (Rq), defined in the ISO 4287 standard, and the variance of the scattered light distribution (Aq), defined in the German VDA2009 standard.

We present a relation between the Aq value measured by the OptoSurf and the ISO standardized Rq parameter. Such relation has not been shown before, but it enables a fast characterization of surface roughness, with an industrial applicable tool. The analyzed samples are made using different methods and therefore have different roughness profiles, hence the presented relations are expected to be valid for most steel surfaces made by a directional processes, such as milling, grinding, or unidirectional polishing. An overview illustrating the conversion from $\mathrm{Aq}$ to $\mathrm{Rq}$ is seen in the attached figure.

Additionally we present a study of the theoretical and empirical changes to the angular scattering distribution, if the sample surface is not properly cleaned but contains a thin liquid film. 